\title{
S2 Figure
}

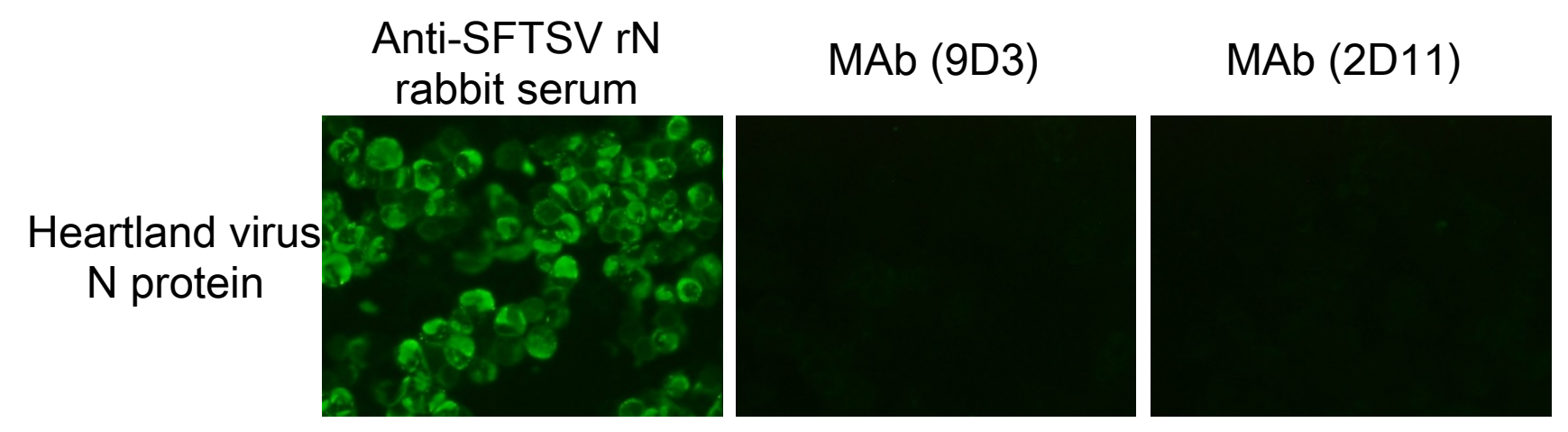

